https://doi.org/10.5219/1554

Received: 25 January 2021. Accepted: 24 March 2021.

Available online: 28 April 2021 at www.potravinarstvo.com

(C) 2021 Potravinarstvo Slovak Journal of Food Sciences, License: CC BY 4.0

ISSN 1337-0960 (online)

\title{
THE STUDY OF SOLUBLE SOLIDS CONTENT ACCUMULATION DYNAMICS UNDER THE INFLUENCE OF WEATHER FACTORS IN THE FRUITS OF CHERRIES
}

\author{
Iryna Ivanova, Maryna Serdiuk, Vira Malkina, Iryna Bandura, Ihor Kovalenko, \\ Tetiana Tymoshchuk, Oksana Tonkha, Oleksandr Tsyz, Mikhailo Mushtruk, Alina Omelian
}

\begin{abstract}
High tasting assessment of the fruit of sweet cherry is due to the favorable soluble solids content (SSC). The weather parameters and varietal features during the formation of fruit have the dominant influence on the accumulation of soluble solids. This issue has gained new relevance in the context of global climate change. The research aimed to develop a dependence of the accumulation of soluble solids of the various sorts of sweet cherries on the weather conditions of the South Steppe zone of Ukraine. Statistical analysis of the values of soluble solids in sweet cherry fruit was performed according to the average indicators of three groups of cultivars. To achieve this goal, the laboratory, factor, correlation, and regression analyses were carried out. The mathematical model was built with the application of factor and regression analysis methods, with the principal component analysis being used. The factor and regression analysis methods became the basis for the linear regression model of dependence of SSC fund accumulation on the influence of climatic parameters for the cultivar types of the three ripening terms. Based on the constructed regression models, we analyzed the degree of influence of the weather parameters on the SSC indicator by calculating the coefficients of $\Delta_{i}$ relative influence. The largest influence was set for the group of temperature and humidity parameters with the maximum share of $\Delta_{i} \geq 9.50 \%$. It was mathematically substantiated that the weather parameters of the last month of fruit formation had the greatest influence on the accumulation of SSC in the sweet cherry fruit, regardless of the period of ripening. For early and medium ripening sweet cherries, those were the weather parameters for May, and for those of late-term of ripening June parameters were of the maximum value.
\end{abstract}

Keywords: pomological variety; ripening terms; principal component analysis; factor analysis; biochemical indicator; cherry

\section{INTRODUCTION}

Sweet cherry is in demand in many countries of the world. The share of sweet cherry fertile plantations in the world is more than $3.1 \%$, which makes about 12.5 thousand hectares. The majority of these plantations $-42.6 \%$ are concentrated in the Middle East and European countries (Durau et al., 2012). Ukraine ranks tenth in the world in terms of sweet cherry fruit production. In 2018, the gross output of the fruit amounted to 84.6 thousand tons, which is about $3.3 \%$ share of the world's production (Zheplinska et al., 2019). According to FAO data, the world market for sweet cherries is undersupplied. According to scientifically based standards, the annual consumption of sweet cherry fruit per capita should be $2 \mathrm{~kg}$ (Winkler and Knoche, 2019). The global production of sweet cherries should reach 14 million tons to ensure such volumes. Now it is 4 million tons.

The fruit of the sweet cherry cultivar, being the first to open the season, is a source of easily digestible monosaccharides and contains a powerful immunostimulatory complex of several valuable nutrients. This is the reason for their popularity not only in Ukraine but also in Hungary, Bulgaria, Turkey, etc. (Blagov et al., 2009). Studies by Canadian and Russian scientists have shown that each variety is characterized by a certain genetically determined biochemical composition (de Carvalho et al., 2019). High testing assessment of sweet cherries is due to favorable soluble solids content. Most dry matter is represented by soluble solids content (SSC), which includes carbohydrates, acids, nitrogen compounds, enzymes, soluble forms of pectin and vitamins, phenolic compounds, mineral salts, etc. (Ivanovych, 2018).

The ratios of soluble solids and insoluble solids according to Ukrainian and foreign researchers (Ivanova, Herasko and Dolhova, 2019) range within the scope of 14.61 $18.98 \%$ and $2.15-2.65 \%$, respectively. The results of many scientific studies proved that the level of soluble solids content affected the intensity and direction of oxidationreduction processes during the storage of fruit and 
determined the choice of process specifications (Basanta et al., 2014). Provided there is a low soluble solids content and excess moisture in the fruit, transpiration processes are intensified (Mikhailik et al., 2014).

Several scientific research traditionally used regression and correlation analyses to assess the degree of influence of parameters on the experimental indicators. However, in conditions when the number of factors for analysis significantly exceeds the number of experimental research, it is not possible to apply a traditional least squares method to build a regression model. Therefore, it has been proposed to build a model using the method of factor analysis principal component analysis (Chigozie, 2012).

\section{Scientific Hypothesis}

Evaluation of climatic conditions during cultivation and selection of rational parameters for obtaining juice from cherry berries will increase the efficiency of the processing process and improve the method of determining the content of soluble solids in various fruit and berry raw materials, which in turn will intensify the process.

\section{MATERIAL AND METHODOLOGY Samples}

To determine the SSC, a sample was taken for each pomological cultivar which consisted of 100 fruit from 6 trees that came into full fruiting. Trees typical of a certain pomological cultivar, of the same age, with a medium intensity of fruiting, were selected for the research. The fruit was weighed and counted in the process of harvesting. The sweet cherries of each commercial cultivar were carefully harvested in the state of consumer ripeness. They were stored and transported to the laboratory provided that the fruit in the period of the indicator determination had the appearance and the taste inherent in the pomological cultivar.

\section{Chemicals}

Chemical reagents were not used for scientific research. Biological Material

The study included sweet cherry fruit of 33 varieties, which were divided into three groups of ripening terms: Group1 - cultivars of the early termination of ripening Sweet Erlise, Merchant, Bigaro Burlat, Rubinova Rannya (Figure 1a), Valeriy Chkalov (Figure 1b), Kazka, Zabuta; Group 2 - cultivars of the medium-term of ripening Cordia, Octavia, Vinka (Figure 1c), Pervistok (Figure 1d), Temp, Uliublenytsia Turovtseva, Talisman, Dilemma, Melitopolska Chorna, Orion, Chervneva Rannya, Dachnytsia, Prostir; Group 3 - cultivars of the late-term of ripening - Karina (Figure 1e), Regina (Figure 1f), Mirazh (Figure 1g), Krupnoplidna, Udivitelna, Zodiac, Siurpryz, Kolkhoznytsia, Kosmichna (Figure 1h), Prazdnichna, Anons, Temporion, Meotyda.

The agricultural background in the areas of the research within the whole period of the research met the requirements of agricultural technology. The accumulation of moisture in the soil mainly takes place in autumn, and partly in winter, and the early spring. The soils of the experimental plots for the cultivation of the crop are the light loamy black humus earth. The forest is the basis for soil formation. According to the aggregate size distribution, this type of soil has a high content of physical sand.
Horticultural farms of the region of research are located in the South Steppe subzone of Ukraine. The landscape of the territory is flat with the Atlantic-continental climate and a high-temperature scenario. The range of average annual air temperature is $9.1-9.9{ }^{\circ} \mathrm{C}$. The average monthly air temperature in the warmest months ranges from 20.5 $2.1^{\circ} \mathrm{C}$. The sum of active temperatures above $10^{\circ} \mathrm{C}$ from April to October is 33 to $16^{\circ} \mathrm{C}$. The average annual rainfall is $475 \mathrm{~mm}$. In terms of rainfall, the region belongs to the area with insufficient moisturization. The average annual relative humidity is within $73 \%$. The average annual wind speed is $3.7 \mathrm{~m} \cdot \mathrm{s}^{-1}$. The climate is arid with the dominance of dry east, north-east winds. The value of the hydrothermal coefficient is within the range of $0.22-0.77$.

\section{Instruments}

Refractometer (ABBE AR12, producer "Inter-Synthesis" Limited Liability Company, Ukraine).

Laboratory hydraulic press (LHP - 25, producer "InterSynthesis" Limited Liability Company, Ukraine).

The meteorological data provided by the meteorological station at Melitopol.

\section{Laboratory Methods}

The SSC was determined by the refractometric method. The essence of the method is based on determining the mass fraction of SSC with the help of a refractive index. The refractive index of the solution under analysis was measured at the temperature of $20.0 \pm 0.5{ }^{\circ} \mathrm{C}$ on the ABBE AR12 refractometer. In the process of sampling, care was taken to ensure that the sample received for the research was representative and was not subject to spoilage during the transportation and storage. The juice was squeezed from the selected average sample with the help of a press. The resulting juice was used for determination. The mass fraction of soluble solids was determined by direct readout of the instrument scale in percent. In case of temperature deviation in the process of measurement, the values of temperature corrections were taken into account. The quality assessment of each pomological cultivar was performed five times (Serdiuk et al., 2020a).

As it is known, the analysis of matching correlation coefficients is an initial but rather rough estimate of the degree of influence of a single factor on the indicator under research. Other instruments of statistical analysis, such as regression and factor analysis, the principal component analysis, should be used to further investigate the issue (Palamarchuk et al., 2019).

However, since the number of considered factors $\mathrm{x}_{\mathrm{j}, \mathrm{j}}=1.25$ in this case, significantly exceeds the number of observations (Y_1i,Y_2i,Y_3i, where $i=1-12$ years of research) it is not possible to apply the classical pattern of regression analysis. Moreover, the factors themselves are strongly correlated with each other, as many interfactor matching correlation coefficients are close to \pm 1 . This indicates the presence of multicollinearity effect.

Therefore, it is proposed to conduct the research of the degree of influence of each of the factors and identify the most significant ones using the method of principal component analysis (PCA). The principal component analysis method allows reducing a large number of variables by constructing artificial factors (principal components $-\left(P C_{i}, i=1 \ldots n\right)$. 


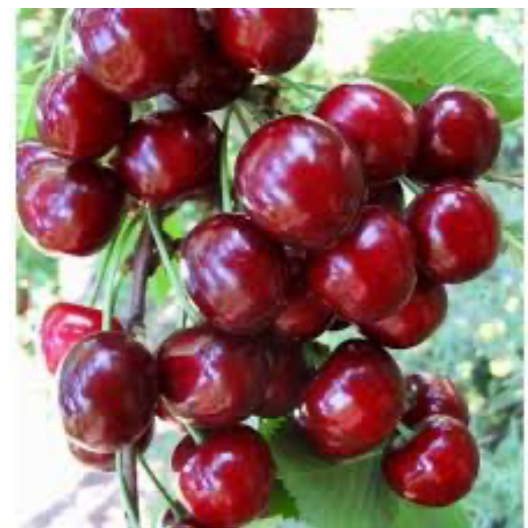

a)

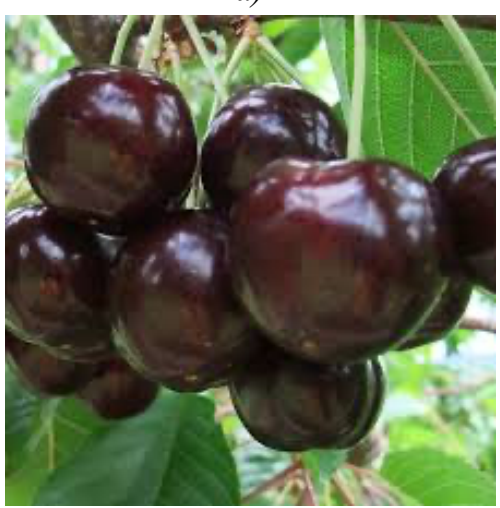

c)

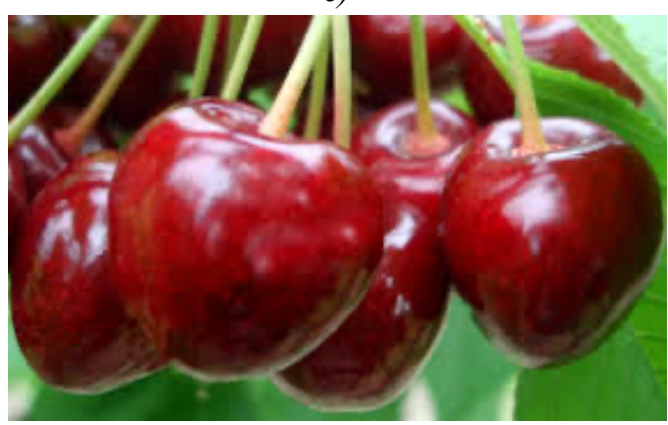

e)

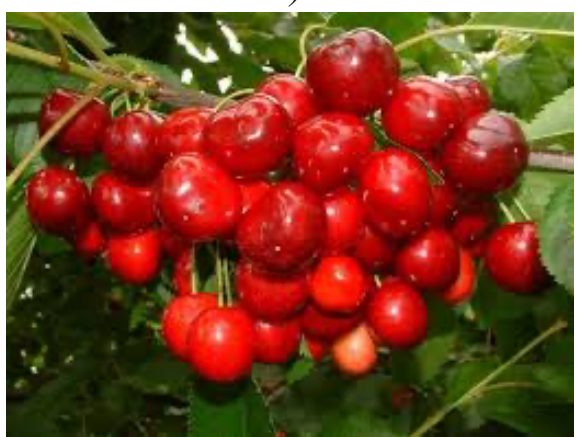

g)

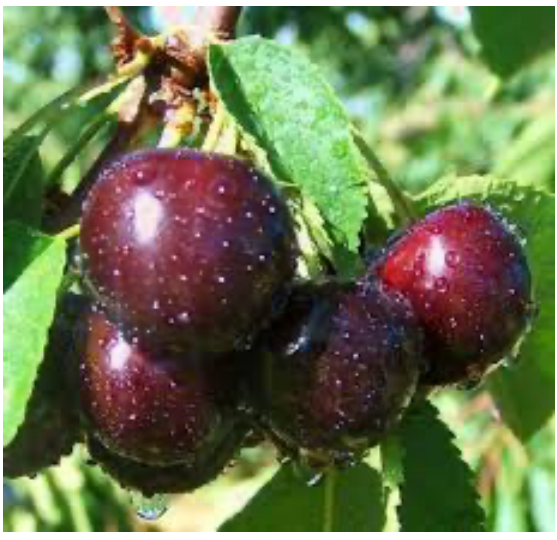

b)

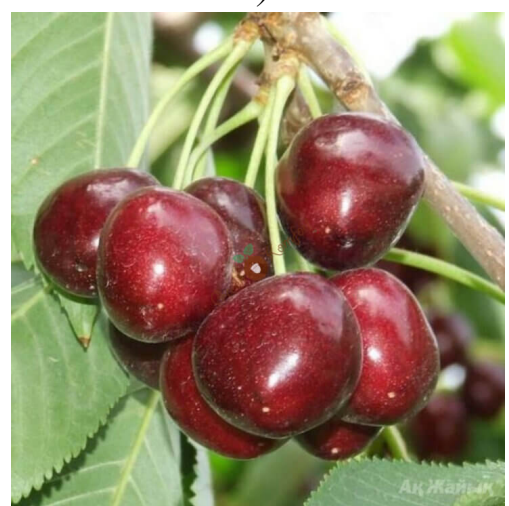

d)

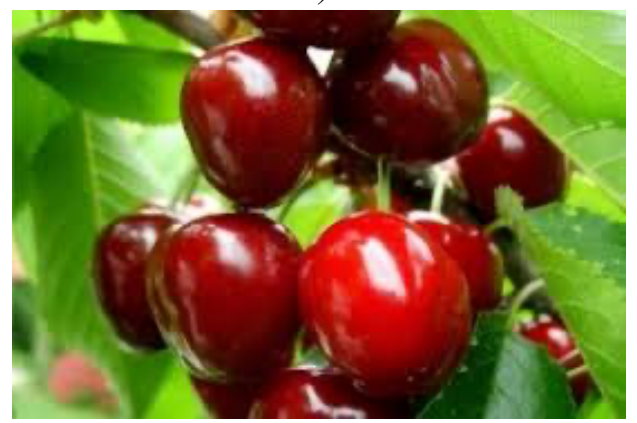

f)

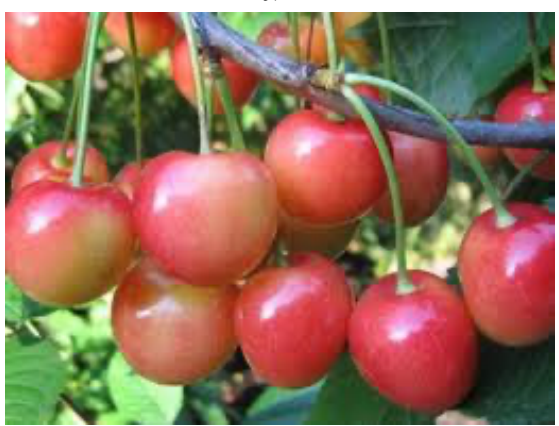

h)

Figure 1 Photos of individual samples of cherries: $a$ - Rubinova Rannya; $b$ - Valeriy Chkalov; $c$ - Vinka, $d$-Pervistok; $e$ - Karina; $f$-Regina; $g$ - Mirazh; $h$ - Kosmichna.

The main components are a linear combination of the original factors $\mathrm{x}_{\mathrm{i}}$ and do not correlate with each other. At the same time, a set of such principal components is distinguished, which extracts the maximum variance from the variables (Palamarchuk et al., 2020; Ming-ming and Jing-lian, 2015; Chen et al., 2018).

Description of the Experiment. The research was conducted during 12 consecutive vegetation periods from
2008 to 2019. During the experiment, we used the meteorological data provided by the meteorological station at Melitopol, Ukraine.

The construction of models of sweet cherry SSC dependence on weather parameters was carried out following the following pattern:

1. Determination of SSC using the above method. 
2. Systematization of information and creation of a database of weather conditions in the years of research. At this stage, the following indicators were selected: average minimum air temperatures, average air temperatures, average maximum air temperatures, absolute minimum air temperatures, absolute maximum air temperatures, precipitation total, average relative humidity, minimum relative humidity, absolute minimum relative humidity.

3. Based on the indicators selected above, the following indicators were calculated: hydrothermal coefficient, temperature differences for certain periods, sums of active temperatures, sums of effective temperatures.

4. Based on the correlation analysis, the weather factors that significantly affect the accumulation of SSC for the sweet cherry of the early, medium, and late-ripening terms were identified.

5. Analysis of the factors defined in Paragraph 4 by methods of factor and regression analysis to determine the degree of influence of each factor on the SSC for the cultivar groups of 3 ripening terms (Ivanova, Herasko and Dolhova, 2019).

\section{Statistical Analysis}

The following pattern of statistical data analysis is proposed:

1. Using the principal component analysis of the given factors (parameters $x_{i j}, i=1 \ldots n$ - number of the weather parameter, $j=1 \ldots m$ - number of the year of research) the set of principal components is composed $\left(P C_{i}, i=1 \ldots n\right)$. Then the initial principal components are determined $\left(P C_{i}, i=1 \ldots k, k \prec n\right)$, which provide the maximum variance - more than $90 \%$ (Chigozie, 2012).

2. Using the least-squares method, the regression dependence of the indicators $Y_{1}, Y_{2}, Y_{3}$ on the principal components $\left(P C_{i}, i=1 \ldots k\right)$ is formed such that:

$$
\hat{Y}_{i}=b_{0}+\sum_{j=1}^{k} b_{j} \cdot P C A_{j}, \quad i=1 \ldots 3,
$$

3. The expressions of the principal components through the initial values of the weather factors $\left(x_{i}, i=1 \ldots n\right)$ are substituted into the regression model (1). After such a transformation, we obtain the regression dependences of the SSC indices on the initial factors for the three groups of cultivars such that:

$$
\hat{Y}_{i}=a_{0}+\sum_{j=1}^{k} a_{j} \cdot x_{j},
$$

Where:

$x_{j}$ shall be factors; $a_{j}$ - shall be model parameters; $\left(\hat{Y}_{i}, i=1 \ldots 3\right)$ shall be SSC indicators for the sweet cherry of the three-cultivar groups.

4. The constructed regressions are analyzed and the degree of influence of each of the factors on the resulting indicators are evaluated. The analysis of the constructed regression is performed based on $\Delta_{i}$ coefficients. These coefficients characterize the relative degree of influence of each of the considered factors $\left(x_{j}, j=1 \ldots n\right)$ on the researched indicator $\left(y_{i}, i=1 \ldots 3\right)$ for the 3 groups of cultivars. The $\Delta_{\mathrm{i}}$ coefficients are calculated according to the formula:

$$
\Delta_{i}=\left|\frac{\widetilde{a}_{i} \cdot r_{y x_{i}}}{R^{2}}\right|
$$

Where: $\widetilde{a}_{i}-$ shall be the parameters of the standardized regression model; $r_{y x_{i}}-$ shall be the matching correlation coefficients; $R^{2}$ - shall be the determination coefficient.

To perform the statistical analysis, the instruments of a modern Data Mining computer technology with RStudio v. 1.3.959 software environment was used.

\section{RESULTS AND DISCUSSION}

The level of soluble solids accumulation can change under the influence of soil and weather conditions, yield, and the degree of fruit ripeness. In the south of Ukraine, the fruit of the best cultivars of sweet cherry contain $12.1-19.9 \%$ of soluble solids, whereas in the central part of the country this indication is only $11.3-12.8 \%$ (Slavin and Lloyd, 2012; Bublyk et al., 2014; Ivanova et al., 2019). The foreign scientists established the change in the biochemical composition of sweet cherry cultivars of different ripening terms depending on the region of cultivation (Cittadini et al., 2008; Basanta et al., 2014; Chen et al., 2018). The dominant influence of weather factors on the accumulation of SSC in comparison with the cultivar characteristics was established in our previous research (Serdiuk et al., 2020b). With that said, the soluble solids content in sweet cherries depends on many factors. However, the decisive influence of weather factors is noted (Sansavini and Lugli, 2008). Given this, the issue of predicting the soluble solids content of sweet cherries depending on the share of weather factors is relevant for the sake of further improvement of transportation and processing technology (Zheplinska et al., 2021).

Year, treatment, and their interaction had significant effects on fruit size, thickness, and weight. Fruit height, the height: width ratio and SSC were not influenced by year and treatment, though the interaction of these factors significantly affected SSC (Bobos et al., 2019).

The difference between daytime and night-time temperatures positively influenced the accumulation of dry solids and sugar content in sweet cherry fruits, whereas the amount of precipitation had a negative impact, forming fissures (Caprio and Quamme, 2006). No direct influence of the amount of rainfall and mean daily temperature on SSC was observed (Sheiko et al., 2019).

Low temperatures during the blooming cause reduction of the yield capacity, but winter frosts and relatively low temperatures during the pollination might also negatively affect yields (Smetanska et al., 2021; Hedhly et al., 2004).

The SSC (consisting mostly of sugars) varies between 11 and $25{ }^{\circ}$ Brix in sweet cherry (Serrano et al., 2005). In general, American consumers preferred sweet cherries with SSC $>16 \%$ (Crisosto et al., 2003). 
The results of twelve years of research suggest that the average content of CPP in cherries grown in the analyzed region was at the level of $16.7 \%$. The average content of CPP in the fruits of cherries of the early maturing varieties was at the level of $15.3 \%$ (Table 1), ie it was $8.4 \%$ lower compared to the average varietal value.

In the fruits of cherries of groups of varieties of medium and late maturity, the average content of SSC exceeded the average varietal value by 1.8 and $7.2 \%$, respectively (Tables 2 and Table 3). Thus, among the studied varieties, the maximum content of SSC was characterized by cherries of the late-ripening group.

The variety of early maturity, which according to the results of twelve years of research was characterized by the largest mass fraction of SSC was Rubinov early, and the smallest - Merchant (Table 1).

Among the varieties of the group of medium maturity, the maximum average content of CPP was recorded in the fruits of the varieties Talisman and Dachnytsia, and the groups of the late group - in the fruits of the variety Udivitelna.

These research results indicate significant variability in the content of SSC over the years of research in the group of varieties of early maturity. The greatest influence of abiotic factors on the content of CPP in the fruits of this group was found for varieties Kazka and Valeriy Chkalov with coefficients of variation of 22.8 and $22.7 \%$, respectively. The most stable in terms of SSC are varieties Zabuta, Merchant, Bigaro Burlat, as evidenced by the corresponding coefficients of variation of $18.4,19.3$, and $19.6 \%$. The variability of these varieties under the influence of weather factors is considered average.

The variability of the SSC content over the years of research in the fruits of cherries of the groups of varieties of medium and late maturity was average $\left(V_{p}=19.6\right.$ and $17.7 \%$, respectively). Among the group of varieties of medium maturity, the most stable dry matter content was in the fruits of the variety Dachnytsia $\left(V_{p}=14 \%\right)$, and the most variable - in the variety Space $\left(V_{p}=29 \%\right)$. In the group of late-maturing varieties, the greatest variability in the content of SSC was recorded in the fruits of the varieties Kolkhoznytsia $\left(V_{p}=21.5 \%\right)$ and Anons $\left(V_{p}=21.6 \%\right)$, the smallest - in the varieties Krupnoplidna $\left(V_{p}=13.4 \%\right)$ and Prazdichna ( $V_{p}=13.7 \%$ ).

Thus, in terms of dry matter content and variability of their formation under the influence of weather factors in the analyzed region, the most promising from a technological point of view were varieties Dachnytsia, medium ripening, and large-ripening varieties Krupnoplidna. These varieties differed in the high content of SSC, and their low variability over the years of research. Among the group of varieties of early maturity of the most promising variety is not identified. All studied varieties with a high content of CPP were characterized by high variability. Varieties Zabuta, Merchant, Bigaro Burlat, in which the variability of SSC content over the years of research was average, were characterized by their low content.

The average cultivar content of SSC in the sweet cherry of 33 researched cultivars grown in the South Steppe subzone of Ukraine was at the level of $16.7 \%$. In the group of cultivars of early ripening, the maximum average SSC is recorded in the fruit of Rubinova Rannya sweet cherries. It was at the level of $16.8 \%$.
Among the cultivars of the other two groups, the fruit of Talisman and Dachnytsia, Krupnoplidna, and Udivitelna cultivars were characterized by the highest average SSC. They accumulated $18.5-18.6 \%$ of SSC. The fruits of cultivars Prostir and Anons, collected in 2015, were characterized by the lowest quantity of dry solutes. The quantity of the dry solutes was lower than the average cultivar value, by 59.8 and $61.7 \%$ accordingly. The highest mass fraction of the dry solutes was recorded in fruits of the Dachnytsia and Karina cultivars, collected in 2012 (Serdiuk et al., 2020a).

To establish the share of the influence of the weather parameters and cultivar characteristics on the formation of SSC of sweet cherry fruit, a two-factor analysis of variance was performed. Its results showed that for all groups of cultivars, regardless of ripeness, the weather parameters of the year of research has the dominant influence on the formation of SSC fund with the share of influence for the cultivars of early ripening being $74.5 \%$, for those of medium ripening $-61.9 \%$ and for the groups of lateripening $-69.4 \%$.

The influence of the characteristics of the cultivar was less significant. The results of the study are presented in more detail in the research of Serdiuk et al. (2020b).

Thus, the results obtained earlier proved the feasibility of predicting the SSC in sweet cherries following

the average values for the certain group of cultivars, and not separately for each pomological cultivar. Medium dependence was found between the fruit weight and the fruit SSC (correlation coefficient 0.53 - 0.59) (Fatih et al, 2014; Kishchak, 2014; Polat et al., 2009). Subsequently, a search was made for the presence of correlations between the index of accumulation of soluble solids in the sweet cherries of early $\left(Y_{1}\right)$, middle $\left(Y_{2}\right)$, late $\left(Y_{3}\right)$ ripening, and the complex of hydrothermal parameters (factors) $-X_{i}$. There were selected 25 indicators of weather factors $\left(X_{i}\right)$ that within the specified growing period can significantly affect the accumulation of SSC in the fruit of sweet cherry of early $\left(Y_{1}\right)$, medium $\left(Y_{2}\right)$, late $\left(Y_{3}\right)$ ripening (Table 1). These thermal indicators of air $\left({ }^{\circ} \mathrm{C}\right)$ shall be the average temperature in May $\left(X_{1}\right)$, June $\left(X_{2}\right)$; absolute minimum temperature in May $\left(X_{3}\right)$, the absolute maximum temperature in May $\left(X_{4}\right)$ June $\left(X_{5}\right)$, the average maximum temperature of April $\left(X_{6}\right)$, May $\left(X_{7}\right)$, June $\left(X_{8}\right)$; average minimum temperature in May $\left(X_{9}\right)$, June $\left(X_{10}\right)$; the annual sum of effective temperatures over $15{ }^{\circ} \mathrm{C}\left(X_{11}\right)$; the difference between the average maximum and minimum temperatures of April $\left(X_{12}\right)$; the sum of active temperatures during the vegetation period $\left(X_{13}\right)$; the average temperature at blossom $\left(X_{14}\right)$; the average minimum temperature at $* *$ The influence of the factor is insignificant, $\Delta_{i} \prec 0.5 \%$ blossom $\left(X_{15}\right)$; the average maximum temperature at blossom $\left(X_{16}\right)$; hydrothermal coefficient at blossom $\left(X_{17}\right)$; the sum of effective temperatures at blossom $\left(X_{18}\right)$. The indicators of humidity (\%) shall be: average relative humidity in May $\left(X_{19}\right)$, June $\left(X_{20}\right)$; absolute minimum relative humidity in May $\left(X_{21}\right)$, June $\left(X_{22}\right)$, at blossom $\left(X_{23}\right)$; average minimum relative humidity at blossom $\left(X_{24}\right)$, the average relative humidity at blossom $\left(X_{25}\right)$. 
Table 1 Dry matter content in cherries cultivars of the early termination of ripening, $\%(2008-2019 \mathrm{yy}),. \bar{x} \pm s \bar{x}, \mathrm{n}=5$.

\begin{tabular}{lcccc}
\hline Pomological variety & $\begin{array}{c}\text { Average content } \\
\text { SSC, \% }\end{array}$ & $\begin{array}{c}\text { min content } \\
\text { SSC, } \%\end{array}$ & $\begin{array}{c}\text { max content } \\
\text { SSC, \% }\end{array}$ & $\begin{array}{c}\text { Variation by years, V } \\
\text { \% }\end{array}$ \\
\hline Rubinova Rannya & $16.8 \pm 3.9$ & 11.7 & 22.6 & 23.3 \\
Valeriy Chkalov & $16.5 \pm 3.7$ & 11.4 & 21.2 & 22.7 \\
Sweet Erlise & $16.2 \pm 3.3$ & 11.7 & 21.2 & 20.4 \\
Merchant & $14.0 \pm 2.7$ & 11.5 & 18.7 & 19.3 \\
Kazka & $14.8 \pm 3.4$ & 10.1 & 20.5 & 22.8 \\
Bigaro Burlat & $13.5 \pm 2.7$ & 10.3 & 18.9 & 19.6 \\
Zabuta & $14.9 \pm 2.7$ & 11.4 & 21.0 & 18.4 \\
Average value & $15.3 \pm 3.3$ & 10.1 & 22.6 & 21.9 \\
HIP 05 & 0.416 & - & - & - \\
\hline
\end{tabular}

Table 2 Dry matter content in cherries cultivars of the medium-term of ripening, $\%(2008-2019$ yy.), $\bar{x} \pm s \bar{x}, \mathrm{n}=5$.

\begin{tabular}{lcccc}
\hline Pomological variety & $\begin{array}{c}\text { Average content } \\
\text { SSC, } \%\end{array}$ & $\begin{array}{c}\text { min content } \\
\text { SSC, } \%\end{array}$ & $\begin{array}{c}\text { max content } \\
\text { SSC, } \%\end{array}$ & $\begin{array}{c}\text { Variation by years, V } \\
\text { \% }\end{array}$ \\
\hline Vinka & $16.8 \pm 3.4$ & 10.9 & 21.7 & 20.0 \\
Pervistok & $16.7 \pm 3.5$ & 10.5 & 21.1 & 21.1 \\
Temp & $17.4 \pm 3.1$ & 12.1 & 22.3 & 17.6 \\
Uliublenytsia Turovtseva & $15.3 \pm 3.0$ & 12.3 & 22.1 & 19.9 \\
Talisman & $18.5 \pm 2.9$ & 15.1 & 23.2 & 16.1 \\
Dilemma & $17.8 \pm 3.3$ & 12.5 & 22.5 & 21.4 \\
Melitopolska Chorna & $17.2 \pm 3.8$ & 12.3 & 22.4 & 15.9 \\
Cordia & $16.6 \pm 2.6$ & 12.0 & 20.0 & 19.5 \\
Octavia & $16.3 \pm 3.2$ & 11.8 & 20.2 & 21.5 \\
Orion & $17.6 \pm 3.8$ & 12.0 & 22.8 & 19.0 \\
Chervneva Rannya & $17.3 \pm 3.3$ & 11.9 & 22.1 & 14.0 \\
Dachnytsia & $18.5 \pm 2.6$ & 15.1 & 23.3 & 29.0 \\
Prostir & $15.7 \pm 4.6$ & 10.0 & 22.0 & 19.6 \\
Average value & $17.0 \pm 3.3$ & 10.0 & 23.3 & - \\
HIP 05 & 0.455 & - & - & \\
\hline
\end{tabular}

Table 3 Dry matter content in cherries cultivars of the late-term of ripening, \% (2008-2019 pp.), $\bar{x} \pm s \bar{x}, \mathrm{n}=5$.

\begin{tabular}{lcccc}
\hline $\begin{array}{c}\text { Pomological } \\
\text { variety }\end{array}$ & $\begin{array}{c}\text { Average content SSC, } \\
\mathbf{\%}\end{array}$ & $\begin{array}{c}\text { min content } \\
\text { SSC, } \%\end{array}$ & $\begin{array}{c}\text { max content } \\
\text { SSC, } \%\end{array}$ & $\begin{array}{c}\text { Variation by years, Vp, } \\
\text { \% }\end{array}$ \\
\hline Krupnoplidna & $18.5 \pm 2.5$ & 13.9 & 22.5 & 13.4 \\
Karina & $18.2 \pm 3.8$ & 12.4 & 23.1 & 20.9 \\
Regina & $17.1 \pm 3.2$ & 12.9 & 22.8 & 18.7 \\
Mirazh & $18.2 \pm 3.5$ & 12.8 & 23.0 & 19.3 \\
Udivitelna & $18.6 \pm 3.5$ & 12.8 & 22.8 & 14.5 \\
Zodiac & $17.0 \pm 2.5$ & 12.9 & 19.7 & 19.0 \\
Siurpryz & $17.9 \pm 3.4$ & 13.0 & 23.0 & 21.5 \\
Kolkhoznytsia & $17.8 \pm 3.8$ & 11.9 & 23.0 & 16.3 \\
Kosmichna & $17.7 \pm 2.9$ & 12.7 & 21.3 & 13.7 \\
Prazdnichna & $16.8 \pm 2.3$ & 11.9 & 19.5 & 21.6 \\
Anons & $17.6 \pm 3.8$ & 10.3 & 21.5 & 18.7 \\
Temporion & $18.3 \pm 3.4$ & 11.2 & 21.5 & 15.9 \\
Meotyda & $18.4 \pm 2.9$ & 11.0 & 22.3 & 17.7 \\
Average value & $17.9 \pm 3.2$ & 10.3 & 23.1 & - \\
HIP 05 & 0.635 & - & - & \\
\hline
\end{tabular}

For these factors the presence of the weak, medium, and strong linear correlations, as evidenced by the values of matching correlation coefficients between values of each factor and the resulting rate $r_{\mathrm{Y}_{1} X_{i}}, r_{\mathrm{Y}_{2} X_{i}}, r_{\mathrm{Y}_{3} X_{i}}$. According to the hypothesis testing of significance of correlation coefficients by Student's test at the significance level of 0.05 significant matching correlation coefficients are within the limit of $r_{\mathrm{Y}_{\mathrm{j}} X_{i}} \geq 0.55, i=1 \ldots 25, j=1 \ldots 3$.

Thus medium ripening cultivars, we identified 17 and, for early and the late-ripening cultivars, there were 16 weather parameters, for which a strong or medium linear correlation dependence with the analyzed indicator (SSC) was established. Further research was carried out according to the pattern given above. 
Table 4 Matching correlation coefficients and meanings of relative share of influence $\left(\Delta_{i}\right)$ for weather parameters $\left(\mathrm{X}_{i}\right.$, and soluble solids content (SSC) in the fruit of sweet cherry of $\operatorname{Early}\left(r_{Y_{1} X_{i}}\right)$, Medium $\left(r_{Y_{2} X_{i}}\right)$, and Late $\left(r_{Y_{3} X_{i}}\right)$ terms of ripening.

\begin{tabular}{|c|c|c|c|c|c|c|}
\hline \multirow{3}{*}{$\begin{array}{c}\text { Conventional Sign of } \\
\text { a Parameter } \\
\left(\mathbf{X}_{i},\right)\end{array}$} & \multicolumn{6}{|c|}{$\begin{array}{l}\text { Matching Correlation Coefficients } r_{Y_{j} X_{i}} \text {, of the Share of }\left(\Delta_{i}\right) \text { Factors Influence for } \\
\text { Cultivar Groups }\end{array}$} \\
\hline & \multicolumn{2}{|c|}{ early } & \multicolumn{2}{|c|}{ medium } & \multicolumn{2}{|c|}{ late } \\
\hline & $r_{Y_{1} X_{i}}$ & $\Delta_{i}, \%$ & $r_{Y_{2} X_{i}}$ & $\Delta_{i}, \%$ & $r_{Y_{3} X_{i}}$ & $\Delta_{i}, \%$ \\
\hline $\mathrm{X}_{1}$ & 0.965 & 14.71 & 0.958 & 13.02 & 0.615 & 1.87 \\
\hline $\mathrm{X}_{2}$ & $0.401 *$ & $* *$ & $0.464^{*}$ & $* *$ & 0.864 & 13.85 \\
\hline $\mathrm{X}_{3}$ & 0.746 & 5.00 & 0.811 & 8.17 & 0.683 & 2.98 \\
\hline $\mathrm{X}_{4}$ & 0.772 & 14.23 & 0.730 & 0.86 & $0.342 *$ & $* *$ \\
\hline $\mathrm{X}_{5}$ & $0.402 *$ & $* *$ & $0.472 *$ & $* *$ & 0.831 & 8.02 \\
\hline $\mathrm{X}_{6}$ & 0.568 & 1.26 & 0.656 & 9.62 & $0.531 *$ & 1.47 \\
\hline $\mathrm{X}_{7}$ & 0.950 & 16.06 & 0.958 & 5.45 & 0.604 & 2.83 \\
\hline $\mathrm{X}_{8}$ & $0.504^{*}$ & $* *$ & 0.540 & $* *$ & 0.823 & 13.98 \\
\hline $\mathrm{X}_{9}$ & 0.934 & 15.94 & 0.901 & 14.18 & 0.701 & 3.11 \\
\hline $\mathrm{X}_{10}$ & $0.375^{*}$ & $* *$ & $0.371 *$ & $* *$ & 0.713 & 9.49 \\
\hline$X_{11}$ & 0.769 & 4.58 & 0.818 & 12.92 & $0.477^{*}$ & $* *$ \\
\hline$X_{12}$ & $0.304 *$ & $* *$ & $0.440^{*}$ & $* *$ & 0.630 & 4.56 \\
\hline $\mathrm{X}_{13}$ & 0.621 & 0.53 & 0.705 & 3.84 & $0.192 *$ & $* *$ \\
\hline $\mathrm{X}_{14}$ & 0.714 & 3.48 & 0.743 & 0.83 & $0.414^{*}$ & $* *$ \\
\hline $\mathrm{X}_{15}$ & 0.557 & 0.87 & $0.492 *$ & 3.22 & $0.225^{*}$ & $* *$ \\
\hline $\mathrm{X}_{16}$ & 0.785 & 2.83 & 0.851 & 2.18 & 0.546 & $* *$ \\
\hline$X_{17}$ & -0.581 & $* *$ & 0.653 & $* *$ & 0.589 & 3.85 \\
\hline $\mathrm{X}_{18}$ & 0.624 & 0.12 & -0.638 & 1.07 & $-0.480^{*}$ & 0.84 \\
\hline $\mathrm{X}_{19}$ & $-0.507 *$ & 0.83 & -0.590 & 0.53 & $-0.068 *$ & $* *$ \\
\hline $\mathrm{X}_{20}$ & $-0.296^{*}$ & $* *$ & $-0.366^{*}$ & $* *$ & -0.571 & 6.99 \\
\hline$X_{21}$ & -0.606 & 9.54 & -0.638 & 12.16 & $-0.155^{*}$ & $* *$ \\
\hline $\mathrm{X}_{22}$ & -0.551 & 0.57 & -0.555 & 2.73 & $-0.229^{*}$ & $* *$ \\
\hline $\mathrm{X}_{23}$ & $-0.300 *$ & 6.84 & $-0.380 *$ & 8.00 & -0.763 & 11.48 \\
\hline$X_{24}$ & -0.658 & $* *$ & -0.720 & $* *$ & -0.685 & 7.94 \\
\hline$X_{25}$ & -0.588 & 1.15 & -0.637 & 1.33 & -0.729 & 9.69 \\
\hline
\end{tabular}

Note: * Insignificant matching correlation coefficients $\left(r_{\mathrm{Y}_{j} X_{i}} \geq 0.55, i=1 \ldots 25, j=1 \ldots 3\right)$ (according to the relevance hypothesis verification by the Student's test with the level of relevance being 0.05 ).

1. Five main components were identified by the principal components method $\left(P C_{i}, i=1 \ldots 5\right)$. These five main components provided more than $90 \%$ of the cumulative proportion of variance.

2. Regression models of the dependence of the soluble solids index for each group of cultivars on the selected main components $\left(P C_{i}, i=1 \ldots 5\right)$ of the form (1) were constructed. The values of the determination coefficient (Adjusted R-squared) for all three regressions are close to one, which indicates a strong influence of independent variables on the dependent variable (Table 5). The $p$-value $<0.05$, which indicates the adequacy of models based on Fisher's test at a significance level of 0.05 .

3. After the transition to the initial factors, we obtain a regression model of the form (2). This regression model characterizes the dependence of the SSC index (for $\hat{Y}_{1}, \hat{Y}_{2}, \hat{Y}_{3}$ ) on weather factors (in standardized factors $\left.\tilde{x}_{i}\right)$

$$
\begin{aligned}
& \hat{Y}_{1}=11.9533+0.30626 \widetilde{x}_{1}+0.1346 \widetilde{x}_{3}+0.3707 \widetilde{x}_{4}+ \\
& +0.0446 \widetilde{x}_{5}+0.3397 \widetilde{x}_{7}+0.34266 \widetilde{x}_{8}+0.1195 \widetilde{x}_{10}- \\
& -0.0172 \widetilde{x}_{12}+0.0980 \widetilde{x}_{14}-0.3792 \widetilde{x}_{15}-0.0345 \widetilde{x}_{16}+ \\
& +0.1120 \widetilde{x}_{18}+0.003184 \widetilde{x}_{19}-0.0329 \widetilde{x}_{21}-0.0190 \widetilde{x}_{22}- \\
& -0.3481 \widetilde{x}_{15}-0.2086 \widetilde{x}_{24}-0.2238 \widetilde{x}_{25} \\
& \hat{Y}_{2}=12.8530+0.2431 \widetilde{x}_{1}+0.1800 \widetilde{x}_{3}+0.0242 \widetilde{x}_{4}+ \\
& +0.2355 \widetilde{x}_{5}+0.1486 \widetilde{x}_{7}+0.2646 \widetilde{x}_{8}+0.2562 \widetilde{x}_{10}+ \\
& +0.0838 \widetilde{x}_{12}-0.0211 \widetilde{x}_{14}+0.03209 \widetilde{x}_{15}-0.0676 \widetilde{x}_{16}- \\
& -0.6099 \widetilde{x}_{18}-0.03234 \widetilde{x}_{19}-0.0148 \widetilde{x}_{21}-0.3914 \widetilde{x}_{22}+ \\
& +0.09913 \widetilde{x}_{15}-0.2207 \widetilde{x}_{24}-0.2531 \widetilde{x}_{25} \\
& \hat{Y}_{3}=13.1095+0.0580 \widetilde{x}_{1}+0.3055 \widetilde{x}_{2}+0.083 \widetilde{x}_{3}+ \\
& 0.1839 \widetilde{x}_{6}-0.0526 \widetilde{x}_{7}+0.0891 \widetilde{x}_{8}+0.3236 \widetilde{x}_{9}+ \\
& +0.0844 \widetilde{x}_{10}-0.2534 \widetilde{x}_{11}+0.1379 \widetilde{x}_{13}+0.1245 \widetilde{x}_{17}- \\
& -0.0332 \widetilde{x}_{18}-0.2331 \widetilde{x}_{20}-0.2869 \widetilde{x}_{23}-0.3914 \widetilde{x}_{22}+ \\
& +0.09913 \widetilde{x}_{15}-0.2207 \widetilde{x}_{24}-0.2531 \widetilde{x}_{25}
\end{aligned}
$$


Table 5 Main regression characteristics of the ssc index from the main components.

\begin{tabular}{ccccccccc}
\hline & \multicolumn{9}{c}{ Coefficients of Regression } & \multicolumn{1}{c}{$\begin{array}{c}\text { Adjusted } \\
\text { R-squared }\end{array}$} & \multicolumn{1}{c}{$\boldsymbol{p}$-value } \\
\cline { 2 - 7 } & $\boldsymbol{b}_{\boldsymbol{0}}$ & $\boldsymbol{b}_{\boldsymbol{1}}$ & $\boldsymbol{b}_{\boldsymbol{2}}$ & $\boldsymbol{b}_{\boldsymbol{3}}$ & $\boldsymbol{b}_{\mathbf{4}}$ & $\boldsymbol{b}_{\boldsymbol{5}}$ & \\
\hline$\hat{Y}_{1}$ & 11.9533 & -0.5675 & 0.23137 & -0.4717 & 0.50313 & 0.17735 & 0.9498 & 0.0001224 \\
$\hat{Y}_{2}$ & 12.85308 & -0.5177 & 0.15739 & -0.1426 & 0.28085 & 0.41546 & 0.9305 & 0.000342 \\
$\hat{Y}_{3}$ & 13.1096 & -0.6491 & 0.27885 & -0.1925 & 0.27026 & 0.01668 & 0.8854 & 0.00862 \\
\hline
\end{tabular}

Based on the constructed models, the coefficients $\Delta_{i},(i=1 \ldots 25)$ are calculated for each factor according to formula (3). The coefficients $\Delta_{i}$ determine the share of each factor in the total variance of the SSC indicator. The results of the calculation are shown in Table 1.

For the cultivars of early and medium ripening terms $\Delta_{i}$ varies within $0.12-16.06 \%$ (Table 1 ), for the late-ripening group this index was $0.84-13.98 \%$. For the further analysis of the research results, the factors depending on the values of coefficients $\Delta_{i},(i=1 \ldots 25)$ were divided into three groups.

The first group includes the factors that have a strong influence on the accumulation of SSC with the value of $\Delta_{i} \geq 9.50 \%$. For the cultivars of early ripening sweet cherries, these include the average monthly, absolute maximum, average maximum, and minimum air temperature in May and absolute minimum relative humidity in May. For the fruit of the medium ripening group, these are the average monthly and average minimum air temperatures in May, the average maximum temperature in April, the sum of annual effective temperatures above $15^{\circ} \mathrm{C}$, and the absolute minimum relative humidity in May. For the fruit of late-ripening, the average monthly, average maximum, and average minimum temperature on June, the absolute minimum, and the average relative humidity in the period of blossom. The second group includes the factors that have an average influence on the accumulation of SSC on the sweet cherry fruit with the meaning of $\Delta_{i}$ from 2.00 $-9.48 \%$ (Table 4 ). The third group includes other factors that have a weak influence on the accumulation of SSC with the meaning of $\Delta_{i} \leq 2.00 \%$ (Table 4 ). The total percentage of the influence of the factors of this group on the cultivars of early ripening is $5.3 \%$, for the cultivars of medium ripening, it is $4.62 \%$, for the late-ripening group it is $4.18 \%$. It was found out that SSC extremely correlated with the time of the blooming, proving the key role of the spring temperatures in the monitoring of the time of flowering (Caprio and Quamme, 2006; Guo et al., 2013; Habib et al., 2017; Menzel et al., 2006; Miller-Rushing et al., 2007).

As a result, the weather conditions of the last month of fruit formation have the greatest influence on the accumulation of SSC in sweet cherry fruit, regardless of the ripening term. For the sweet cherry cultivars of early and medium ripening, these are the weather conditions of May, for the late-ripening cultivars it is June.

\section{CONCLUSION}

1. A correlation analysis was performed among 25 weather factors $\left(\mathrm{X}_{i},\right)$ and the SSC in the sweet cherry of early $\left(r_{Y_{1} X_{i}}\right)$, medium $\left(r_{Y_{2} X_{i}}\right)$, late $\left(r_{Y_{3} X_{i}}\right)$ terms of ripening. Strong and average linear correlation among 17 weather factors $\left(\mathrm{X}_{\mathrm{i}}\right.$ ) and $\mathrm{SSC}$ for early, medium ripening sweet cherries and 16 climate parameters for the lateripening $\left(r_{\mathrm{Y}_{\mathrm{j}} X_{i}} \geq 0.55, i=1 \ldots 25, j=1 \ldots 3\right)$.

2. Based on the methods of factor and regression analysis, linear regression models of the dependence of SSC fund accumulation on the influence of weather factors on the groups of cultivars of the early, medium, and lateripening terms.

3. Based on the constructed regression models, the analysis of the degree of influence of weather factors on the SSC indicator was performed by calculating the coefficients of relative influence $\Delta_{i}, \%$. The greatest influence is established for the group of temperature and humidity indicators with the maximum share of participation $\Delta_{i} \geq 9.50 \%$.

4. It was mathematically substantiated that the weather conditions of the last month of fruit formation have the greatest influence on the accumulation of SSC in the sweet cherry fruit, regardless of the ripening term. For the sweet cherry cultivars of early and medium ripening, these are the weather conditions of May, for the late-ripening cultivars it is June.

5. It is established that in terms of dry matter content and variability of their formation in regions with climatic conditions of the Southern steppe subzone of Ukraine the most promising from the technological point of view were varieties Dachnytsia, medium maturity, and variety Krupnoplidna, late maturity. These varieties differed in the high content of dry soluble substances and their low variability over the years of research.

\section{REFERENCES}

Basanta, M. F., Ponce, N. M. A., Salum, M. L., Rafo, M. D., Vicento, A. R., Erra-Balsolls, R., Stort, C. A. 2014. Compositional changes in cell wall polysaccharides from five sweet cherry (Prunus avium L,) cultivars during on-tree ripening. Journal of Agricultural and Food Chemistry, vol. 62, no. 51, p. 12410-12427. https://doi.org/10.1021/jf504357u

Blagov, A., Christov, N., Sotirov, D., Stoyanova, A. 2009. Comparison of some new apple and sweet cherry cultivars under the environmental conditions of Kyustendil, Bulgaria. Acta Horticulturae, vol. 825, p. 89-96. https://doi.org/10.17660/ActaHortic.2009.825.10

Bobos, I. M., Fedosy, I. O., Tonkha, O. L., Zavadska, O.V., Olt, J. R. 2019. Optimization of plant densities of dolichos 
(Dolichos lablab 1. var. lignosus) bean in the right-bank of forest-steppe of Ukraine. Agronomy Research, vol. 17, no. 6, p. 2195-2202

Bublyk, M. O., Fryziuk, L. A., Levchuk, L. M. 2014. Fruit crop production distribution in Ukraine: A research note. Chemistry and Chemical Biology: Methodologies and Applications, vol. 9, no. 18, p. 207-218.

Caprio, J. M., Quamme, H. A. 2006. Influence of weather on apricot, peach and sweet cherry production in the Okanagan Valley of British Columbia. Canadian journal of plant science, vol. 86, no. 1, p. 259-267. https://doi.org/10.4141/P05-032

Chen, L., Wu, Y., Cheng, H., Li, Y., Zhao, Y. 2018. A new middle ripening sweet cherry cultivar «Linglongcui». Acta Horticulturae Sinica, vol. 45, no. 7, p. 1419-1420.

Chigozie, A. K. 2012. Regression and principal component analyses: a comparison using few regressors. American Journal of Mathematics and Statistics, vol. 2, no. 1, p. 1-5. https://doi.org/10.5923/j.ajms.20120201.01

Cittadini, E. D., Keulen van, H., Ridder de, N., Peri, P. L., Rodriguez, M. J. 2008. Fruit dry weight and quality of 'Bing' sweet cherries grown without source limitations. Acta Horticulturae, vol. 795, no. 2, p. 639-644. https://doi.org/10.17660/ActaHortic.2008.795.99

Crisosto, C. H., Crisosto, G. M., Metheney, P. 2003. Consumer acceptance of 'Brooks' and 'Bing' cherries is mainly dependent on fruit SSC and visual skin color. Postharvest Biology and Technology, vol. 28, no. 1, p. 159167. https://doi.org/10.1016/S0925-5214(02)00173-4

de Carvalho, L., de Carvalho, H., de Barros, I., Martins, C., Soares Filho, W., Girardi, E., Passos, O. 2019. New scionrootstock combinations for diversification of sweet orange orchards in tropical hardsetting soils. Scientia Horticulturae, vol. 243, p. 169-176. https://doi.org/10.1016/j.scienta.2018.07.032

Durau, A., Croitoru, M., Dima, M. 2012. Achievements and perspectives on stone fruit growing on sandy soils. Fruit Growing Research, vol. 28, no. 1, p. 107-109.

Fatih, S., Rustu, O., Golkarian, M., Yaldiz, S. 2014. Quality Changes of Different Sweet Cherry Cultivars at Various Stages of the Supply Chain. Notulae Botanicae Horti Agrobotanici Cluj-Napoca, vol. 42, no. 2. p. 501-506. https://doi.org/10.15835/nbha4229596

Guo, L., Dai, J., Ranjitkar, S., Xu, J., Luedeling, E. 2013. Response of chestnut phenology in China to climate variation and change. Agric. For Meteorol., vol. 180, p. 164-172. https://doi.org/10.1016/j.agrformet.2013.06.004

Habib, M., Bhat, M., Dar, B. N., Wani, A. A. 2017. Sweet cherries from farm to table: A review. Critical Reviews in Food Science and Nutrition, vol. 57, no. 8, p. 1638-1649. https://doi.org/10.1080/10408398.2015.1005831

Hedhly, A., Hormaza, J., Herrero, M. 2004. Effect of temperature on pollen tube kinetics and dynamics in sweet cherry, Prunus avium (Rosaceae). Am. J. Bot., vol. 91, p. 558564. https://doi.org/10.3732/ajb.91.4.558

Ivanova, I. Y., Herasko, T. V., Dolhova, S. V. 2019. Analysis of the biochemical composition of fresh and fresh frozen sweet cherries of three terms of ripening grown under the conditions of South Steppe zone of Ukraine. Tavriya Scientific Bulletin, vol. 105, p. 160-165. https://doi.org/10.32851/22260099.2019.108.20 (in Ukrainian)

Ivanova, I. Y., Serdiuk, M. Y., Herasko, T. V., Bilous, E. S., Kryvonos, I. A. 2019. Cherry yield depending on the climatic conditions of the cultivation years. Ukrainian Black Sea region agrarian science, vol. 3 , no. 3 , p. 61-70. https://doi.org/10.31521/2313-092X/2019-4(104)-5
Ivanovych, Y. I. 2018. Genetic profiling for marker-mediated selection of cherries cultivars (Prunus avium L,) of Ukrainian selection. Extended abstract of Candidate's thesis, Kyiv, 23 p.

Kishchak, O. A. 2014. Scientific bases of industrial cherry variety in the forest-steppe zone of Ukraine : extended abstract of Doctor's thesis. Kyiv, Ukraine.

Menzel, A., Sparks, T. H., Estrella, N., Koch, E., Aasa, A., Ahas, R., Alm-Kübler, K., Bissolli, P., Braslavská, O., Briede, A. Chmielewski, F. M., Crepinsek, Z., Curnel, Y., Dahl, Å., Defila, C., Donnelly, A., Filella, Y., Jatczak, K., Måge, F., Mestre, A., Nordli, Ø., Peñuelas, J., Pirinen, P., Remišová, V., Scheifinger, H., Stirz, M., Susnik, A., Van Vliet, A. J. H., Wielgolaski, F.-E., Zach, S., Zust, A. 2006. European phenological response to climate change matches the warming pattern. Glob Chang Biol, vol. 12, p. 1969-1976. https://doi.org/10.1111/j.1365-2486.2006.01193.x

Mikhailik, V. A., Dmitrenko, N. V., Snezhkin, Y. F. 2014. Change in the specific heat capacity of parenchymal tissues of apples due to dehydration. Journal of Engineering Physics and Thermophysics, vol. 87. no. 1, p. 48-53. https://doi.org/10.1007/s10891-014-0983-7

Miller-Rushing, A. J., Katsuki, T., Primack, R. B., Ishii, Y., Lee, S. D., Higuchi, H. 2007. Impact of global warming on a group of related species and their hybrids: cherry tree (Rosaceae) flowering at Mt. Takao, Japan. Am. J. Bot., vol. 94, no. 9, p. 1470-1478. https://doi.org/10.3732/ajb.94.9.1470

Ming-ming, Ch., Jing-lian, M. 2015. Application of principal component regression analysis in economic analysis. Proceedings of the 3rd International Conference on Management Science, Education Technology, Arts, Social Science and Economics, p. 1205-1208. ISBN 978-94-6252-1285. https://doi.org/10.2991/msetasse-15.2015.255

Palamarchuk, I., Mushtruk, M., Sukhenko, V., Dudchenko, V., Korets, L., Litvinenko, A., Deviatko, O., Ulianko, S., Slobodyanyuk, N. 2020. Modelling of the process of vybromechanical activation of plant raw material hydrolysis for pectin extraction. Potravinarstvo Slovak Journal of Food Sciences, vol. 14, no. 1, p. 239-246. https://doi.org/10.5219/1305

Palamarchuk, I., Mushtruk, M., Vasyliv, V., Zheplinska, M. 2019. Substantiation of regime parameters of vibrating conveyor infrared dryers. Potravinarstvo Slovak Journal of Food Sciences, vol. 13, no. 1, p. 751-758. https://doi.org/10.5219/1184

Polat, A. A., Durga, C., Kamiloglu, O. 2009. Determination of fruit quality parameters of sweet cherries grown in high elevation regions in Hatay, Turkey. Acta Horticulturae, vol. 795, no. 2, p. 873-876. https://doi.org/10.17660/ActaHortic.2008.795.141

Sansavini, S., Lugli, S. 2008. Sweet cherry breeding programs in Europe and Asia. Acta Horticulture, vol. 795, p. 41-58. https://doi.org/10.17660/ActaHortic.2008.795.1

Serdiuk, M. E., Priss, O. P., Haprindashvili, N. A., Ivanova, I. Y. 2020a. Research methods of horticulture products. Melitopol, Ukraine : Liuks.

Serdiuk, M. Y., Ivanova, I. Y., Malkina, V. M., Kryvonos, I. A., Tymoshchuk, T. M., Ievstafiieva, K. S. 2020b. The formation of dry soluble substances in sweet cherry fruits under the influence of abiotic factors. Scientific horizons, vol. 88, no. 3, p. 127-135. https://doi.org/10.33249/2663-2144-2020-88-3127-135

Serrano, M., Guillén, F., Martínez-Romero, D., Castillo, S., Valero, D. 2005. Chemical constituents and antioxidant activity of sweet cherry at different ripening stages. Journal of Agricultural and Food Chemistry, vol. 53, p. 2741-2745. https://doi.org/10.1021/jf0479160 
Sheiko, T., Tkachenko, S., Mushtruk, M., Vasyliv, V., Deviatko, O., Mukoid, R., Bilko, M., Bondar, M. 2019. The Studying the processing of food dye from beet juice. Potravinarstvo Slovak Journal of Food Sciences, vol. 13, no. 1, p. 688-694. https://doi.org/10.5219/1152

Slavin, J., Lloyd, B. 2012. Health benefits of fruit and vegetables. An International Review Journal, vol. 3, no. 4, p. 506-516. https://doi.org/10.3945/an.112.002154

Smetanska, I., Tonkha, O., Patyka, T., Hunaefi, D., Mamdouh, D., Patyka, M., Bukin, A., Mushtruk, M., Slobodyanyuk, N., Omelian, A. 2021. The influence of yeast extract and jasmonic acid on phenolic acids content of in vitro hairy root cultures of Orthosiphon aristatus. Potravinarstvo Slovak Journal of Food Sciences, vol. 15, no. 1, p. 1-8. https://doi.org/10.5219/1508

Winkler, A., Knoche, M. 2019. Calcium and the physiology of sweet cherries: A review. Scientia horticulturae, vol. 245, p. 107-115. https://doi.org/10.1016/j.scienta.2018.10.012

Zheplinska, M., Mushtruk, M., Vasyliv, V., Deviatko, O. 2019. Investigation of the process of production of crafted beer with spicy and aromatic raw materials. Potravinarstvo Slovak Journal of Food Sciences, vol. 13, no. 1, p. 806-814. https://doi.org/10.5219/1183

Zheplinska, M., Mushtruk, M., Vasyliv, V., Sarana, V., Gudzenko, M., Slobodyanyuk, N., Kuts, A., Tkachenko, S., Mukoid, R. 2021. The influence of cavitation effects on the purification processes of beet sugar production juices. Potravinarstvo Slovak Journal of Food Sciences, vol. 15, no. 1, p. 18-25. https://doi.org/10.5219/1494

\section{Contact address:}

Iryna Ivanova, Dmitro Motorniy Tavria State Agrotechnological Agrotechnologies and Ecology, Department of Horticulture, Viticulture and Biochemistry, B. Khmelnytsky Ave. 18 B, 72312, Melitopol, Ukraine, Tel.: +380979684745 ,

E-mail: irynaivanova2017@gmail.com

ORCID: http://orcid.org/0000-0003-2711-2021

Maryna Serdiuk, Dmitro Motorniy Tavria State Agrotechnological University, Faculty of Agrotechnologies and Ecology, Department of Food Technology and Hotel-Restaurant Business, B. Khmelnytsky Ave. 18 B, 72312, Melitopol, Ukraine,

E-mail: kowtun.marina@gmail.com

ORCID: http://orcid.org/0000-0002-6504-4093

Vira Malkina, Dmitro Motorniy Tavria State Agrotechnological University, Faculty of Energy and Computure Technology, B. Khmelnytsky Ave. 18 B, 72312, Melitopol, Ukraine,

E-mail: vmmalkina@gmail.com

ORCID: https://orcid.org/0000-0002-2076-2032
Iryna Bandura, Dmitro Motorniy Tavria State Agrotechnological University, Faculty of Agrotechnologies and Ecology, Department of Food Technology and Hotel-Restaurant Business, B. Khmelnytsky Ave. 18 B, 72312, Melitopol, Ukraine, Tel.: +380677209304,

E-mail: irabandura@gmail.com

ORCID: https://orcid.org/0000-0001-7835-3293

Ihor Kovalenko, Sumy National Agrarian University, Faculty of Agrotechnologies and Natural Resource Management, Department of Ecology and Botany, Herasym Kondratiev Str. 160, 40000, Sumy,

E-mail: kovalenko 977@ukr.net

ORCID: https://orcid.org/0000-0003-4957-2352

Tetiana Tymoshchuk, Polissia National University, Faculty of Agronomy, Department of Plant Protection, Staryi Blvd 7, 10008, Zhytomyr, Ukraine,

E-mail: tat-niktim@ukr.net

ORCID: https://orcid.org/0000-0001-8980-7334

Oksana Tonkha, National University of Life and Environmental Sciences of Ukraine, Agrobiological Faculty, Department of Soil Science and Soil Protection them prof. M. K. Shykuly, Heroiv Oborony Str. 15, 03041, Kyiv, Ukraine, Tel.: +380975447440,

E-mail: oksana16095@gmail.com

ORCID: https://orcid.org/0000-0002-0677-5494

Oleksandr Tsyz, National University of Life and Environmental Sciences of Ukraine, Agrobiological Faculty, Department of Vegetable Crops and Greenhouses, Heroiv Oborony Str. 15, 03041, Kyiv, Ukraine, Tel.: +380675068754,

E-mail: tsyzom@gmail.com

ORCID: https://orcid.org/0000-0001-7174-7011

*Mikhailo Mushtruk, National University of Life and Environmental Sciences of Ukraine, Faculty of Food Technology and Quality Control of Agricultural Products, Department of Processes and Equipment for Processing of Agricultural Production, Heroes of Defense Str., 12 B, Kyiv, 03040, Ukraine, Tel.: +38(098)941-26-06,

E-mail: mixej.1984@ukr.net

ORCID: https://orcid.org/0000-0002-3646-1226

Alina Omelian, National University of Life and Environmental Sciences of Ukraine, Faculty of Food Technology and Quality Control of Agricultural Products, Department of Technologies of Meat, Fish and Seafoods, Heroiv Oborony Str., 15, Kyiv, 03040, Ukraine, Tel.: +380987846045,

E-mail: alina.omelyan@outlook.com

ORCID: https://orcid.org/0000-0002-4148-4801

Corresponding author: * 